\title{
Reaksi Investor atas Pengungkapan Internet Financial Reporting
}

\author{
William Indra S. Mooduto \\ Program Pasca Sarjana Universitas Brawijaya Malang \\ Jl. MT. Haryono 165, Malang. \\ E-mail:william.mooduto@gmail.com
}

\begin{abstract}
The purpose of this research was to examine investor reactions on internet financial reporting. This research also examined the factors that affect investor reactions on internet financial reporting, by examining the influence of the degree of information disclosure and the scope of internet reporting. In addition, this research also compared the speed of investor reactions between a company that provides a greater degree of IFR disclosure and a company that provides a less degree of IFR disclosure. The samples were selected by purposive sampling criteria. The number of samples were 295 companies listed on the Indonesian Stock Exchange in 2012. The research was conducted using event studies, multiple regression analysis techniques, and final prediction error (FPE) methodology. The results showed that investors react to the presence of internet financial reporting disclosures, as indicated by the presence of abnormal return in the event window. The results also showed that the investor reaction is influenced by the level of information in the IFR disclosure. While the scope of the disclosure IFR can't explain the cause of the reaction of investors. In addition, the results also showed that there was no difference the speed of investor reactions between a company that provides a greater degree of IFR disclosure and a company that provides a less degree of IFR disclosure.
\end{abstract}

Keywords: internet financial reporting, investor reaction, abnormal return.

\section{PENDAHULUAN}

Perkembangan Inovasi teknologi informasi dan komunikasi yang pesat meningkatkan kemampuan perusahaan dalam menyediakan informasi bagi stakeholders perusahaan, khususnya investor. Penemuan besar pada abad ini yang sangat mendukung perkembangan informasi dan komunikasi tersebut adalah internet. Internet memiliki beberapa karakteristik dan keunggulan seperti mudah menyebar (pervasiveness), dan mempunyai interaksi yang tinggi (high interaction) (Asbaugh et al., 1999). Olehkarena itu, Internet menawarkan berbagai kemungkinan untuk menyajikan informasi keuangan dengan kualitas dan kuantitas yang lebih tinggi, biaya yang lebih murah dan bisa menjangkau para pemakai secara luas tanpa halangan geografis (Xiao et. al, 2002).

Hadirnya internet sebagai media informasi memunculkan sebuah gagasan baru dalam dunia akuntansi tentang penyajian laporan keuangan melalui internet atau dikenal dengan Internet Financial Reporting (IFR). IFR adalah suatu mekanisme pengungkapan laporan keuangan perusahaan melalui internet atau melalui situs web yang dimiliki oleh perusahaan. Perusahaan yang menerapkan praktek IFR terdiri dari perusahaan-perusahaan yang mengungkapkan: (1) laporan keuangan secara keseluruhan termasuk catatan kaki, (2) laporan keuangan semesteran dan/atau; (3) informasi keuangan penting seperti ringkasan dari laporan keuangan melalui website perusahaan (Oyelere et al. 2003, Mohamad et al., 2003, dan Momany \& Al-Shorman, 2006). Laporan keuangan melalui internet pada website perusahaan disajikan dengan tiga cara, yaitu: (1) Menduplikasi laporan keuangan yang paper based ke dalam bentuk electronic paper; (2) Mengubah laporan keuangan ke dalam bentuk HTML; (3) Meningkatkan publikasi

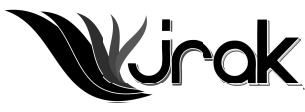

Jurnal Reviu Akuntansi dan Keuangan ISSN: 2088-0685 Vol.3 No. 2, Oktober 2013 Pp 479-492 
Reaksi

Investor...

laporan keuangan melalui situs web perusahaan sehingga lebih memudahkan pihak yang berkepentingan untuk mengakses laporan keuangan dengan cepat (Venter, 2002).

Pada tahun 2006, lebih dari 70\% perusahan besar di dunia telah menerapkan IFR (Kahn, 2006). Salah satu faktor pendorong meningkatnya penggunaan IFR, karena IFR menawarkan suatu bentuk pengungkapan yang luas sebagai media bagi perusahaan dalam menyediakan informasi kepada publik sesegera mungkin (Abdelsalam \& El-Masry, 2008). Fenomena penggunaan IFR oleh perusahaanperusahaan terlebih lagi didorong oleh adanya himbauan-himbauan dari beberapa regulator dan lembaga yang menetapkan standar, termasuk bursa saham. Misalnya American Securities and Exchange Commission (SEC) pada 10 Agustus 2000 mengharuskan perusahaan yang go public untuk mengungkapkan informasi tentang kondisi dan kinerja perusahaan kepada publik daripada pasar yang dipilih (Momany dan Shorman, 2006).

Berdasarkan hasil survey Almilia (2009) terhadap perusahaan yang terdaftar di Bursa Efek Indonesia (BEI), terdapat $62 \%$ perusahaan yang telah memiliki website untuk mempublikasikan beberapa informasi tentang kondisi keuangan dan non keuangan perusahaan. Hal ini menunjukan adanya praktik pengungkapan IFR di Indonesia. Namun, pengungkapan IFR ini, baik kualitas maupun kuantitasnya belum terstandarisasi. Dewan Standar Akuntansi Keuangan Indonesia belum mengatur atau mengesahkan peraturan tentang pengungkapan IFR. Oleh karena itu, perusahaan memiliki kebebasan dalam mengungkapkan informasi keuangan melalui internet.

Pengungkapan IFR menarik minat peneliti, karena pengungkapan IFR merupakan salah satu alat signaling yang mampu memberikan berbagai sinyal tentang prospek perusahaan. Terdapat dua alat untuk mengirimkan informasi kepada publik mengenai prospek masa depan perusahaan yaitu earning dan dividen (Aharony dan Sway, 1980). Kedua hal ini diungkapkan dalam IFR. Informasi dalam pengungkapan IFR apabila mempunyai arti bagi para investor, maka akan mengakibatkan perubahan harga saham di pasar modal. Terjadinya perubahan harga saham tersebut mengindikasikan adanya reaksi investor atas pengungkapan IFR, baik bereaksi positif maupun negatif. Investor bereaksi positif ataupun negatif tergantung dari hasil interpretasi informasi tersebut sebagai berita baik (good news) atau berita buruk (bad news).

Penelitian yang dilakukan oleh Lai et al. (2010) di perusahaan-perusahaan yang terdaftar pada Bursa Efek Taiwan memberikan bukti bahwa pengungkapan IFR berpengaruh terhadap abnormal return. Disamping penelitian Lai et al. (2010), Ashbaugh et al. (1999) menunjukan bahwa elemen penting dari IFR adalah tingkat atau kuantitas pengungkapan. Semakin tinggi tingkat pengungkapan informasi, maka semakin besar dampak pengungkapan pada keputusan investor. Akan tetapi, Penelitian Akhirudin (2013) yang dilakukan di Indonesia menunjukan bahwa pengungkapan IFR tidak berpengaruh terhadap abnormal return.

Berdasarkan perbedaan tersebut, maka penelitian ini bermaksud menguji kembali pengaruh pengungkapan IFR terhadap abnormal return dan diharapkan dapat menjembatani perbedaan yang terdapat pada penelitian terdahulu.

\section{Kerangka Konseptual \& Perumusan Hipotesis}

Kerangka konseptual ini didasarkan pada efficient market theory dan Signaling theory. Efficient market theory menjelaskan reaksi investor atas publikasi informasi perusahaan untuk mencapai harga keseimbangan baru yang sepenuhnya mencerminkan informasi yang tersedia. Efficient market terbentuk berdasarkan tiga macam informasi, yaitu informasi masa lalu, informasi sekarang yang sedang dipublikasikan dan informasi privat (Fama, 1970). Efficient market yang dimaksudkan dalam penelitian ini adalah efficient market yang terbentuk dari informasi yang dipublikasikan sekarang atau dikenal dengan efficient mar- 
ket bentuk setengah kuat. Pasar dikatakan efisiensi dalam bentuk setengah kuat, jika harga-harga sekuritas secara penuh mencerminkan (fully reflect) semua informasi yang dipublikasikan (all publicy available information) termasuk informasi yang berada dilaporan keuangan perusahaan emiten (Hartono, 2010). Informasi yang dimasudkan dalam penelitian ini adalah informasi dalam pengungkapan IFR.

Signaling theory digunakan sebagai dasar menguji kandungan informasi dalam peristiwa pengungkapan IFR. Signaling theory mengemukakan tentang cara perusahaan memberikan signal kepada investor. Signal ini berupa informasi tentang kinerja perusahaan, baik informasi keuangan maupun non keuangan dalam pengungkapan IFR, sehingga signal ini dapat mempengaruhi reaksi investor yang tercermin dalam perubahan harga saham, yang ditunjukan dengan adanya abnormal return saham perusahaan.

Adanya reaksi investor terhadap pengungkapan Internet Financial Reporting (IFR) dipengaruhi oleh tingkat informasi dan ruang lingkup pengungkapan Internet Financial Reporting (IFR). Tingkat informasi dan ruang lingkup pengungkapan IFR merupakan elemen penting dari IFR. Semakin tinggi tingkat kuantitas pengungkapan informasi, semakin besar dampak dari pengungkapan IFR pada keputusan investasi investor (Ashbaugh et al., 1999). Disamping itu, tingkat pengungkapan IFR yang tinggi cenderung mempunyai abnormal return yang lebih besar dan perubahan harga saham bergerak lebih cepat. (Lai et al., 2010).

\section{Reaksi Investor atas Pengungkapan IFR}

Pengungkapan pelaporan keuangan melalui internet merupakan informasi yang disampaikan oleh pihak manajemen perusahaan ke pihak eksternal, khususnya investor. Informasi ini dapat mempengaruhi reaksi Investor. Investor akan merespon informasi tersebut sebagai sinyal terhadap adanya peristiwa (event) tertentu. Respon para investor terhadap pengungkapan pelaporan keuangan melalui internet dapat berupa respon positif atau respon negatif. Investor akan memberikan respon positif jika informasi yang dipublikasikan adalah goodnews dan investor akan memberikan respon negatif jika informasi yang dipublikasikan adalah badnews (Akhirudin, 2013).

Beaver (1968) menyatakan bahwa perusahaan akan mengungkapkan informasi sebanyak mungkin, sehingga investor mampu membedakan perusahaan yang baik dan buruk. Pengungkapan sukarela di internet, baik berupa informasi keuangan maupun informasi non keuangan menciptakan transparansi informasi yang lebih besar, sehingga dapat mempengaruhi reaksi investor. Reaksi investor ditunjukkan dengan adanya perubahan harga saham dan dapat diukur dengan menggunakan abnormal return saham. Berdasarkan penelitian Lai et al., (2010) menemukan bahwa perusahaan yang menerapkan IFR dengan tingkat pengungkapan informasi yang tinggi cenderung mempunyai abnormal return yang lebih besar dan perubahan harga saham bergerak lebih cepat. Hal ini menunjukan adanya reaksi investor terhadap pengungkapan IFR. Disamping itu, perubahan harga saham bergerak lebih cepat mengindikasikan kecepatan reaksi investor terhadap tingkat pengungkapan IFR. Olehkarena itu, hipotesis pertama dari penelitian ini dirumuskan sebagai berikut:

$\mathbf{H}_{1:}$ Investor bereaksi terhadap pengungkapan Internet Financial Reporting (IFR)

\section{Pengaruh Tingkat Informasi \& Ruang Lingkup Pengungkapan IFR terhadap Reaksi Investor}

Investor akan bereaksi apabila ada informasi yang relevan memasuki pasar. IFR merupakan pengungkapan sukarela yang berisi informasi, baik berupa informasi keuangan maupun non-keuangan. Pengungkapan IFR ini bisa menjadi stimulus bagi investor untuk mengambil tindakan dalam keputusan investasi yang 
Reaksi

Investor...

akan merubah keseimbangan pasar. Secara otomatis hal ini akan mempengaruhi transaksi perdagangan saham, misalnya volume perdagangan saham, frekuensi perdagangan saham, dan harga saham.

Pengungkapan IFR mempercepat akses investor terhadap informasi yang diberikan. Kecepatan informasi yang diterima oleh investor melalui IFR memperpendek delay aksesibilitas informasi, sehingga harga saham perusahaan yang menerapkan IFR bersifat responsive. Perubahan harga saham dipengaruhi oleh kuantitas dan kualitas informasi yang diungkapkan oleh perusahaan. Penelitian Easley et al. (2004) membuktikan bahwa kuantitas dan kualitas informasi mempengaruhi harga saham dalam kesetimbangan. Disamping itu, penelitiannya menunjukan bahwa investor yang memperoleh informasi lebih relevan, meningkatkan return yang lebih tinggi pada investasinya.

Senada dengan Easley et al. (2004), Ashbaugh et al. (1999) menunjukkan bahwa elemen penting dari IFR adalah tingkat atau kuantitas pengungkapan. Semakin tinggi tingkat kuantitas pengungkapan informasi, semakin besar dampak pengungkapan terhadap keputusan investasi yang dilakukan oleh investor. Penelitian Lai et al., (2010) menemukan bahwa perusahaan yang menerapkan IFR dengan tingkat pengungkapan informasi yang tinggi cenderung mempunyai abnormal return yang lebih besar dan perubahan harga saham bergerak lebih cepat. Disamping itu, ruang lingkup pengungkapan IFR mempengaruhi abnormal return. Dengan demikian, maka hipotesis kedua dan ketiga yang diajukan adalah:

$\mathbf{H}_{2}$ : Tingkat Pengungkapan Internet Financial Reporting (IFR) berpengaruh terhadap abnormal return saham

$\mathbf{H}_{3}$ : Ruang Lingkup Pengungkapan Internet Financial Reporting (IFR) berpengaruh terhadap abnormal return saham

\section{Kecepatan Reaksi Investor atas Pengungkapan IFR}

Pengujian kandungan informasi hanya menguji reaksi dari pasar, tetapi tidak menguji seberapa cepat pasar itu bereaksi. Jika pengujian melibatkan kecepatan reaksi dari pasar untuk menyerap informasi yang diumumkan, maka pengujian ini merupakan pengujian efisiensi pasar secara informasi bentuk setengah kuat. Pasar dikatakan efisien bentuk setengah kuat jika investor bereaksi dengan cepat untuk menyerap abnormal return untuk menuju ke harga keseimbangan yang baru (Hartono, 2010).

Berdasarkan penelitian Lai et al., (2010), harga saham berubah lebih cepat pada perusahaan yang pengungkapan IFR tinggi daripada perusahaan yang pengungkapan IFR rendah. Disamping itu, Lai et al., (2010) menunjukan bahwa semakin tinggi pengungkapan IFR yang dilakukan perusahaan, maka semakin tinggi pula abnormal return yang diperoleh perusahaan. Dengan demikian, maka hipotesis penelitian yang keempat dapat dirumuskan sebagai berikut.

$\mathbf{H}_{4}$ : Investor bereaksi lebih cepat pada perusahaan dengan tingkat pengungkapan IFR tinggi daripada perusahaan dengan tingkat pengungkapan IFR rendah.

\section{METODE}

Populasi dalam penelitian ini adalah seluruh perusahaan yang terdaftar di Bursa Efek Indonesia (BEI) tahun 2012. Sampel dipilih dengan menggunakan metode purposive sampling dengan tipe judgement sampling, yakni teknik penentuan sampel yang disesuaikan dengan tujuan penelitian dan dilakukan berdasarkan pertimbangan tertentu (Sekaran, 2006). 


\begin{tabular}{lc}
\hline \multicolumn{1}{c}{ Keterangan } & Jumlah \\
\hline Perusahaan yang terdaftar di BEI tahun 2012 & 465 \\
$\begin{array}{l}\text { Perusahaan yang tidak memiliki situs web resmi (officiall } \\
\text { website) yang dapat diakses }\end{array}$ & (97) \\
$\begin{array}{l}\text { Perusahaan yang tidak mempublikasikan laporan keuangan di } \\
\text { website perusahaan }\end{array}$ & $\mathbf{2 9 5}$ \\
\hline Total Sampel
\end{tabular}

Perusahaan yang tidak memiliki situs web resmi (officiall website) yang dapat diakses

\section{Definisi Operasional \& Pengukuran Variabel}

1. Reaksi Investor

Variabel dependen pada penelitian ini adalah reaksi investor. Reaksi investor diukur dengan menggunakan abnormal return. abnormal return merupakan selisih dari actual return dan expected return. Rumus abnormal return sebagai berikut:

Keterangan:

$A \boldsymbol{R}_{i . t}=\boldsymbol{R}_{\text {i.t }}-\boldsymbol{E}\left(\boldsymbol{R}_{i . t}\right)$

$\boldsymbol{A R}_{\text {i.t }} \quad=$ Abnormal return saham ke-i pada periode peristiwa ke-t

$\boldsymbol{R}_{i . t}=$ Actual return yang terjadi untuk saham ke-i pada periode peristiwa ke-t

$\boldsymbol{E}\left(\boldsymbol{R}_{i . t}\right)=$ Expected return saham ke-i untuk periode peristiwa ke-t

Expected return dihitung dengan menggunakan market model. Model ekspektasi dapat dibentuk menggunakan teknik regresi OLS (Ordinary Least Square) dengan persamaan sebagai berikut:

Keterangan:

$\mathbf{E} \mathbf{R}_{\mathrm{i} . \mathrm{t}}=\boldsymbol{\alpha}_{\mathbf{i}}+\boldsymbol{\beta}_{\mathbf{i} \cdot \mathbf{R}} \mathbf{R}_{\mathrm{mt}}+\varepsilon_{\mathrm{it}}$

$\boldsymbol{E R}_{\text {i.t }}=$ Expected return saham ke-i untuk periode peristiwa ke-t

$\mathbf{a}_{\mathbf{i}} \quad=$ Intercept untuk saham i

$\mathbf{b}_{\mathbf{i}} \quad=$ Beta saham $\mathrm{i}$

$\mathbf{R}_{\mathrm{mt}} \quad=$ Return pasar harian pada hari ke $\mathrm{t}$ selama periode estimasi

$\mathbf{e}_{\mathbf{i t}} \quad=$ Kesalahan residu saham I pada hari ke $\mathrm{t}$ selama periode estimasi

Persamaan untuk mencari expected return digunakan pada rumus untuk mencari abnormal return sebagai berikut:

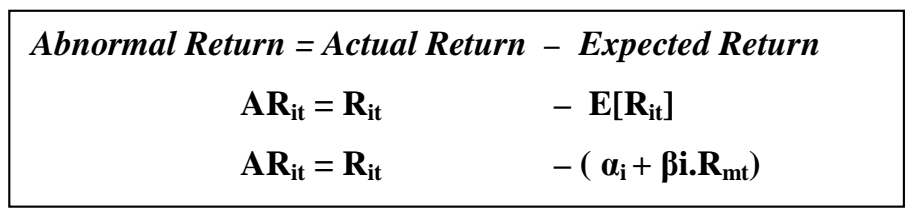

Keterangan:

$\mathrm{AR}_{\mathrm{it}}=$ abnormal return saham i pada hari ke-t

$\mathrm{R}_{\mathrm{it}}=$ actual return untuk saham i pada hari ke-t 
Reaksi

Investor...
$\mathrm{R}_{\mathrm{mt}}=$ return pasar pada hari ke-t

$\alpha_{i}=$ intercept untuk sekuritas ke-i

$\beta_{i}=$ koefisien slope, yang merupakan beta dari sekuritas ke-i

Tahap-tahap untuk menentukan komponen dalam rumus untuk mencari $a b-$ normal return adalah sebagai berikut:

a. Menghitung return saham individual harian $\left(\mathrm{R}_{\mathrm{it}}\right)$ setiap periode, dengan rumus:

$R_{\text {it }}=\frac{\mathrm{P}_{\text {it }}-\mathrm{P}_{\mathrm{it}-1}}{\mathrm{P}_{i t-1}}$

Keterangan:

$\mathrm{R}_{\mathrm{it}} \quad=$ return saham harian i pada hari ke $\mathrm{t}$

$\mathrm{P}_{\mathrm{it}} \quad$ = harga saham i pada hari ke $\mathrm{t}$

$\mathrm{P}_{\mathrm{it}-1}=$ harga saham i pada hari ke $\mathrm{t}-1$

b. Menghitung return pasar harian dengan rumus:

$$
R_{\mathrm{mt}}=\frac{\mathrm{P}_{\mathrm{mt}}-\mathrm{P}_{\mathrm{mt}-1}}{\mathrm{P}_{m t-1}}
$$

Keterangan:

$\mathrm{R}_{\mathrm{mt}}=$ return pasar harian

$\mathrm{P}_{\mathrm{mt}}=$ IHSG pada hari ke $\mathrm{t}$

$\mathrm{P}_{\mathrm{mt}-1}=$ IHSG pada hari ke $\mathrm{t}-1$

c. Menghitung â (beta)

Expected return dengan menggunakan market model, dapat menghitung $\beta$ (beta) berdasarkan rumus sebagai berikut:

$\mathbf{R}_{\mathrm{i} . \mathrm{t}}=\alpha_{\mathrm{i}}+\beta_{\mathrm{i}} \cdot \mathbf{R}_{\mathrm{mt}}+\varepsilon_{\mathrm{it}}$

Keterangan:

$\boldsymbol{R}_{i . t}=$ return saham ke-i harian pada hari ke $\mathrm{t}$ selama periode estimasi

$\boldsymbol{\alpha}_{\mathbf{i}}=$ Intercept untuk saham i

$\boldsymbol{\beta}_{\mathrm{i}} \quad=$ Beta saham i yang diperoleh dari teknik regresi

$\mathbf{R}_{\mathrm{mt}}=$ Return pasar harian pada hari ke $\mathrm{t}$ selama periode estimasi

$\boldsymbol{\varepsilon}_{\mathbf{i t}} \quad=$ Kesalahan residu saham I pada hari ke t selama periode estimasi

2. Internet Financial Reporting

Variabel independen terdiri dari tingkat pengungkapan IFR dan ruang lingkup IFR.

a). Tingkat Pengungkapan IFR

Pengukuran tingkat pengungkapan informasi IFR diadopsi dari penelitian Ettredge et al. (2001) yang telah dikembangkan oleh Lai et al. (2010) dengan menggunakan sistem skala 4 poin tertimbang untuk menilai setiap item informasi yang diungkapkan. Item pengungkapan informasi terdiri dari 5 Item pengungkapan, yaitu profil dasar perusahaan, berita terbaru, item operasional, informasi keuangan, dan informasi saham.

Pengungkapan item informasi Profil dasar perusahaan diberi poin 1; berita terbaru dibei poin 1; item operasional diberi poin 1; laporan keuangan singkat diberi poin 2; laporan keuangan tahunan lengkap diberi 
poin 3; Iaporan tahunan (annual report) dewan direki diberi poin 4; dan informasi saham diberi poin 1 . Total poin berkisar antara 0 sampai 40 . I tem pengungkapan dan skala penilaiannya dapat dilihat dalam tabel 2

\begin{tabular}{|c|c|c|c|}
\hline $\begin{array}{l}\text { Tipe Pengungkapan } \\
\text { Informasi }\end{array}$ & & Item Pengukuran & Nilai \\
\hline \multirow{7}{*}{ Profil Dasar } & 1 & Sejarah \& Profil Perusahaan & 1 \\
\hline & 2 & Strategi, Kebijakan Operasi \& Budaya Perusahaan & 1 \\
\hline & 3 & Informasi Produk \& Layanan & 1 \\
\hline & 4 & Tim Manajemen \& Organisasi Perusahaan & 1 \\
\hline & 5 & Informasi Sumber Daya Manusia & 1 \\
\hline & 6 & Konglomerasi \& Investasi & 1 \\
\hline & 7 & Informasi Kontak & 1 \\
\hline \multirow{3}{*}{ Berita } & 1 & Informasi Industri & 1 \\
\hline & 2 & Informasi Produk \& Operasi & 1 \\
\hline & 3 & Berita Terbaru Seputar Keuangan & 1 \\
\hline \multirow{3}{*}{ Item Operasional } & 1 & Profil Operasi & 1 \\
\hline & 2 & Ramalan \& Tujuan Operasi & 1 \\
\hline & 3 & Analisis Industri \& Laporan Penelitian Terkait & 1 \\
\hline \multirow{11}{*}{ Informasi Keuangan } & 1 & Informasi Keuangan Tertentu & 1 \\
\hline & 2 & Laporan Keuangan Kuartal Singkat & 2 \\
\hline & 3 & Laporan Keuangan Tengah Tahunan Singkat & 2 \\
\hline & 4 & Laporan Keuangan Tahunan Singkat & 2 \\
\hline & 5 & Laporan Keuangan Kuartal Lengkap & 3 \\
\hline & 6 & Laporan Keuangan Tengah Tahunan Lengkap & 3 \\
\hline & 7 & Laporan Keuangan Tahunan Lengkap & 3 \\
\hline & 8 & Laporan Tahunan Dewan Direksi & 4 \\
\hline & 9 & Informasi Pendapatan Bulanan Operasional & 1 \\
\hline & 10 & Analisis Keuangan & 1 \\
\hline & 11 & Ramalan Keuangan & 1 \\
\hline \multirow{4}{*}{ Informasi Saham } & 1 & Informasi Harga Saham Historis \& Deviden & 1 \\
\hline & 2 & Kebijakan Deviden & 1 \\
\hline & 3 & Informasi Harga Saham Terkini & 1 \\
\hline & 4 & Informasi Agen Saham & 1 \\
\hline Jumlah & & & 40 \\
\hline
\end{tabular}

b). Ruang Lingkup IFR

Ruang lingkup I FR didefinisikan sebagai luasnya website pusat perusahaan terhubung dengan website-website lain di dalam atau di luar perusahaan untuk membentuk struktur websiteinter atau intra-perusahaan (Lai et al.,2010). Tujuan dari hubungan ini adalah untuk memberikan informasi tambahan. Situs-situs lain meliputi : (1) Bursa E fek I ndonesia, (2) anak perusahaan atau divisi utama, (3) unit bisnis strategis, dan (4) up-stream perusahaan seperti pemasok dan produsen, dan hilir perusahaan seperti grosir, pengecer, dan pelanggan lainnya. Pengukuran ruang lingkup IF R mengadopsi metode yang digunakan ol eh Ashbaugh et al. (1999) dan Craven dan Marston (1999). Setiap jenis jaringan yang terhubung dengan website perusahaan diberikan satu poin, sehingga total poin berkisar 0 sampai 4 poin. (lihat tabel 3).

\begin{tabular}{llc}
\hline \multicolumn{1}{c}{ Item Pengukuran } & Nilai \\
\hline 1 & $\begin{array}{l}\text { Website perusahaan terhubung dengan Bursa Efek } \\
\text { Indonesia }\end{array}$ & 1 \\
2 & $\begin{array}{l}\text { Website perusahaan terhubung dengan anak perusahaan } \\
\text { atau divisi utama }\end{array}$ & 1 \\
3 & $\begin{array}{l}\text { Website perusahaan terhubung dengan unit bisnis } \\
\text { strategi }\end{array}$ & 1 \\
4 & $\begin{array}{l}\text { Website perusahaan terhubung dengan up-stream \& } \\
\text { down-stream Perusahaan }\end{array}$ & 1 \\
\hline
\end{tabular}

Tabel 2

Item Pengungkapan dan Skala Penilaian
Tabel 3

Item Pengukuran Ruang Lingkup IFR 
Reaksi

Investor...
Teknik Analsis Data

Analisis data dilakukan dalam tiga tahap utama, Tahap pertama, menguji adanya kandungan informasi yang dimasudkan untuk melihat reaksi investor atas pengungkapan IFR. Pengujian ini dilakukan melalui studi peristiwa (event study), yang menguji adanya kandungan informasi dari pengungkapan IFR ditandai dengan adanya abnormal return pada jendela peristiwa. Pengujian signifikansi abnormal return menggunakan one sample $t$-test. Tahap kedua, menguji faktor-faktor yang mempengaruhi reaksi investor atas pengungkapan IFR, yaitu menguji pengaruh tingkat informasi dan ruang lingkup pengungkapan terhadap reaksi investor. Pengujian ini dilakukan dengan menggunakan teknik multiple regression. Tahap ketiga, menguji kecepatan reaksi investor antara perusahaan yang tingkat pengungkapan IFR tinggi dan perusahaan yang tingkat pengungkapan IFR rendah. Pengujian ini dilakukan dengan menghitung final prediction error dari autoregressive dan kemudian melakukan pengujian independent sampel t-test.

\section{HASIL DAN PEMBAHASAN}

\section{Pengujian Abnormal Return}

Hipotesis pertama $\left(\mathrm{H}_{1}\right)$ menyatakan bahwa investor perusahaan bereaksi terhadap pengungkapan internet financial reporting. Untuk mengetahui reaksi investor perusahaan terhadap pengungkapan internet financial reporting, maka dilakukan pengujian average abnormal return (AAR) pada periode jendela peristiwa. Jumlah perusahaan yang diuji signifikansi average abnormal return (AAR)-nya adalah 295 perusahaan. Hasil pengujian signifikansi adalah pada tabel 4 berikut.

\begin{tabular}{cccc}
\hline Hari ke- t & AARt & t hitung & Signifikansi \\
\hline $\mathbf{- 5}$ & $-0,0081$ & $-3,663$ & $0,000^{*}$ \\
$\mathbf{- 4}$ & $-0,0010$ & $-0,588$ & 0,557 \\
$\mathbf{- 3}$ & $-0,1634$ & $-2,244$ & $0,026^{*}$ \\
$\mathbf{- 2}$ & $-0,0075$ & $-4,047$ & $0,000^{*}$ \\
$\mathbf{- 1}$ & $-0,0051$ & $-0,990$ & 0,323 \\
$\mathbf{0}$ & $-0,0213$ & $-2,265$ & $0,024^{*}$ \\
$\mathbf{1}$ & 0,0074 & 1,585 & 0,114 \\
$\mathbf{2}$ & $-0,0227$ & $-2,099$ & $0,037^{*}$ \\
$\mathbf{3}$ & $-0,0333$ & $-2,181$ & $0,030^{*}$ \\
$\mathbf{4}$ & $-0,0064$ & $-1,435$ & 0,152 \\
$\mathbf{5}$ & 0,0126 & 1,725 & 0,086 \\
\hline
\end{tabular}

\section{Keterangan:}

$\mathrm{AAR}_{\mathrm{t}}=$ Average Abnormal Return pada hari ke $\mathrm{t}$

$*$ Signifikan pada level á $=5 \%\left(p^{-}\right.$value $\left.<0,05\right)$

Berdasarkan tabel 4 dapat dilihat bahwa terdapat abnormal return pada jendela peristiwa, akan tetapi rata-rata abnormal return sahamnya bernilai negatif. Abnormal return yang signifikan terjadi pada hari $\mathrm{t}-5, \mathrm{t}-3, \mathrm{t}-2, \mathrm{t} 0, \mathrm{t} 2$, dan $\mathrm{t} 3$.

\section{Pengujian Tahap Kedua Menggunakan Multiple Regression}

Pengujian hipotesis bertujuan untuk menguji pengaruh variabel tingkat pengungkapan dan ruang lingkup pengungkapan IFR terhadap cumulative $a b^{-}$ 
normal return dengan menggunakan analisis multipleregression. Hasil pengolahan menggunakan program aplikasi SPSS adalah sebagai berikut.

$\mathrm{CAR}_{\mathrm{it}}=\beta_{0}+\beta_{1}$ TPIFR $+\beta_{2}$ RLIFR $+\varepsilon$

\begin{tabular}{ccccc}
\hline Variabel & $\begin{array}{c}\text { Koefisien } \\
\text { Regresi }\end{array}$ & $\begin{array}{c}\text { Standard } \\
\text { Error }\end{array}$ & Nilai t & Nilai p \\
\hline TPIFR & $-0,025$ & 0,011 & $-2,358$ & 0,019 \\
RLIFR & 0,081 & 0,085 & 0,959 & 0,338 \\
\hline
\end{tabular}

Berdasarkan tabel 5 dapat dilihat bahwa tingkat pengungkapan IFR memiliki pengaruh signifikan terhadap cumulative abnormal return, sedangkan ruang lingkup IFR tidak berpengaruh terhadap cumulative abnormal return. Dengan demikian, hasil penelitian dalam tabel 5 menerima hipotesis $2\left(\mathrm{H}_{2}\right)$ dan menolak hipotesis $3\left(\mathrm{H}_{3}\right)$.

\section{Pengujian Tahap Ketiga Menggunakan Autoregressive dan FPE}

Pengujian pada tahap ketiga ini bertujuan untuk mengetahui kecepatan reaksi investor terhadap pengungkapan IFR. Untuk mengetahui kecepatan rekasi investor terhadap pengungkapan I FR, maka penelitian ini membandingkan kecepatan perubahan harga saham pada perusahaan yang tingkat pengungkapan IFRnya tinggi dan perusahaan yang tingkat pengungkapan IF Rnya rendah. Pengujian kecepatan perubahan harga saham menggunakan final prediction error (FPE) berdasarkan permodelan autoregressive. Final prediction error (FPE) yang digunakan dalam penelitian ini adal ah Final prediction er ror yang dikembangkan ol eh Akaike (1969) atau dikenal dengan Akaike's information criteria (AIC).

Untuk menguji hipotesis 4, dilakukan pemisahan 295 perusahaan ke dalam dua kel ompok, yaitu kelompok pertama adalah perusahaan dengan total skor pengungkapan IF R diatas rata-rata dan kel ompok kedua adalah per usahaan dengan total skor pengungkapan IFR dibawah rata-rata. Kemudian menghitung final prediction error (FPE) berdasarkan permodel an autoregressive. Berikut hasil perhitungan FPE.

\begin{tabular}{llccc}
\hline Perusahaan & N & Mean & Std. Deviation & Std. Error Mean \\
\hline Kelompok 1 & 46 & 8,5188 & 2,4420688 & 0,2000621 \\
Kelompok 2 & 46 & 8,3323 & 2,8324141 & 0,2344123 \\
\hline
\end{tabular}

Berdasarkan tabel 6 dapat dilihat bahwa nilai rata-rata final prediction error untuk perusahaan kelompok pertama sebesar 8,5188 dan untuk perusahaan kel ompok kedua sebesar 8,3323. Hal ini menunjukan bahwa nilai FPE perusahaan dengan total skor pengungkapan IFR diatas rata-rata lebih besar dari nilai FPE perusahaan dengan total skor pengungkapan IFR dibawah rata-rata, tetapi secara statistik tidak ada perbedaan yang signifikan. Hal ini dapat dilihat pada tabel 7 berikut ini.

\begin{tabular}{ccccc}
\hline $\mathbf{t}$ & df & Sig.(P-Value) & Mean Differeance & Std. Error Mean \\
\hline$-0,606$ & 293 & 0,545 & $-0,1865284$ & 0,3077158 \\
\hline
\end{tabular}


Reaksi

Investor...

tinggi dan pada perusahaan yang pengungkapan IFRnya rendah. Oleh karena itu, hipotesis 4 ditolak (P.value $>0.05$ ).

\section{Reaksi Investor atas pengungkapan IFR}

Pengujian hipotesis pertama adalah pengujian adanya reaksi investor yang tercermin pada abnormal return terhadap pengungkapan IFR. Abnormal return yang signifikan terjadi pada hari ke $\mathrm{t}-5, \mathrm{t}-3, \mathrm{t}-2$, $\mathrm{t} 0$, $\mathrm{t} 2$, dan $\mathrm{t} 3$ di jendela peristiwa yang diamati (tabel 4). Hal ini berarti hipotesis pertama $\left(\mathrm{H}_{1}\right)$ diterima, yakni bahwa investor perusahaan bereaksi terhadap pengungkapan IFR. Hasil penelitian ini mendukung penelitian Lai et al. (2010) dan Akhirudin (2013).

Terjadinya abnormal return saham pada jendela peristiwa menunjukan bahwa pengungkapan IFR mengandung informasi, sehingga direspon oleh pasar. Adanya abnormal return yang signifikann terjadi pada hari ke $\mathrm{t}-5, \mathrm{t}-3$, dan $\mathrm{t}-2$ mengindikasikan adanya kebocoran informasi karena abnormal return terjadi sebelum publikasi informasi di Internet atau website perusahaan. Kebocoran informasi diduga disebabkan adanya perbedaan waktu antara publikasi laporan keuangan melalui internet dan penyampaian laporan keuangan ke Bursa Efek Indonesia. Sebagian besar perusahaan terlebih dahulu menyampaikan laporan keuangan ke Bursa Efek Indonesia (BEI) daripada mempublikasikan laporan keuangan melalui internet atau website perusahaan.

Munculnya abnormal return sejak tanggal pengungkapan IFR menunjukan pasar yang efisien secara informasi dan keputusan. hasil penelitian ini menunjukan bahwa secara informasi, pasar modal di Indonesia adalah efisien bentuk setengah kuat, karena harga saham mencerminkan secara penuh (fully reflect) semua informasi yang dipublikasikan (all publicly available information). Terbukti bahwa pengungkapan IFR mempengaruhi harga saham perusahaan. Pengujian efisiensi pasar bentuk setengah kuat dilakukan dengan melihat seberapa cepat harga saham menggambarkan informasi yang dipublikasikan (Hartono, 2010). Hasil penelitian ini menunjukan bahwa pasar modal di Indonesia adalah efisiensi bentuk setengah kuat secara keputusan. Hal ini ditunjukan dengan kecepatan pasar bereaksi dimulai sejak hari terjadinya pengungkapan IFR $\left(\mathrm{t}_{0}\right)$ oleh emiten.

\section{Hubungan Tingkat pengungkapan IFR dan Abnormal Return}

Hipotesis kedua $\left(\mathrm{H}_{2}\right)$ menyatakan bahwa tingkat pengungkapan IFR berpengaruh terhadap abnormal return saham perusahaan. Berdasarkan hasil uji regresi pada tabel 5., menunjukan bahwa tingkat pengungkapan IFR berpengaruh terhadap abnormal return saham perusahaan. Artinya tingkat pengungkapan IFR dapat menjelaskan besarnya abnormal return. Hal ini menunjukan bahwa hipotesis kedua $\left(\mathrm{H}_{2}\right)$ diterima.

Hasil penelitian ini mendukung penelitian Lai et al. (2010) yang menyatakan bahwa semakin tinggi tingkat pengungkapan IFR, semakin tinggi abnormal return saham perusahaan. Berbeda dengan hasil penelitian Lai et al. (2010), hasil penelitian ini tidak konsisten dengan penelitian Akhirudin (2013) yang menemukan bahwa tingkat pengungkapan IFR tidak berpengaruh terhadap $a b^{-}$ normal return saham perusahaan. Berdasarkan teori pasar modal efisien, yang mengatakan bahwa pada pasar yang efisien semua informasi relevan yang masuk ke dalam pasar akan direspon oleh investor, dan hal ini tercermin pada terjadinya abnormal return.

\section{Hubungan Ruang Lingkup pengungkapan IFR dan Abnormal Return}

Hipotesis ketiga $\left(\mathrm{H}_{3}\right)$ menyatakan bahwa ruang lingkup pengungkapan IFR berpengaruh terhadap abnormal return saham perusahaan. Berdasarkan hasil uji regresi pada tabel 5, menunjukan bahwa ruang lingkup pengungkapan IFR tidak berpengaruh terhadap abnormal return saham perusahaan. Artinya ruang lingkup IFR tidak dapat menjelaskan besarnya abnormal return. Hal ini menunjukan bahwa hipotesis ketiga $\left(\mathrm{H}_{3}\right)$ ditolak. 
Hasil penelitian ini bertentangan dengan penelitian Lai et al. (2010) yang menyatakan bahwa semakin tinggi ruang lingkup pengungkapan IFR, semakin tinggi abnormal return saham perusahaan. Kecilnya prosentase ruang lingkup pengungkapan IFR dapat menjadi penyebab variabel luasnya ruang lingkup pengungkapan IFR tidak berpengaruh secara signifikan terhadap abnormal return saham perusahaan. Pasar modal di Indonesia masih merupakan pasar modal yang tipis (thin market). Pasar modal yang tipis merupakan ciri pasar modal yang sedang berkembang, sehingga investor perusahaan mempertimbangkan faktorfaktor lain dalam memberikan reaksi terhadap luasnya ruang lingkup pengungkapan IFR.

\section{Kecepatan Reaksi Investor atas Pengungkapan IFR}

Hipotesis keempat $\left(\mathrm{H}_{4}\right)$ menyatakan bahwa investor bereaksi lebih cepat pada perusahaan yang tingkat pengungkapan IFR tinggi daripada perusahaan yang tingkat pengungkapan IFR rendah. Berdasarkan hasil T-Test pada tabel 7, menunjukan bahwa tidak ada perbedaan yang signifikan antara kecepatan reaksi investor pada perusahaan yang tingkat pengungkapan IFR tinggi dan perusahaan yang tingkat pengungkapan IFR Rendah. Hal ini menunjukan bahwa hipotesis keempat $\left(\mathrm{H}_{4}\right)$ ditolak.

Hasil penelitian ini tidak konsisten dengan penelitian Lai et al. (2010) yang menyatakan bahwa harga saham berubah lebih cepat pada perusahaan yang tingkat pengungkapan IFR tinggi daripada perusahaan yang tingkat pengungkapan IFR rendah. Perubahan harga saham dengan cepat merupakan indikasi kecepatan reaksi investor.

\section{SIMPULAN}

Penelitian ini bertujuan untuk menguji reaksi investor perusahaan atas pengungkapan internet financial reporting (IFR) dan faktor-faktor yang mempengaruhi reaksi investor atas pengungkapan IFR. Penelitian ini juga menguji kecepatan reaksi investor antara perusahaan yang tingkat pengungkapan IFR tinggi dan perusahaan yang tingkat pengungkapan IFR rendah.

Hasil penelitian menunjukan bahwa investor bereaksi terhadap pengungkapan internet financial reporting (IFR) tanpa memperhatikan ruang lingkup pengungkapan IFR. Reaksi investor atas pengungkapan internet financial reporting (IFR) ditunjukkan dengan adanya abnormal return pada jendela peristiwa. Abnormal return yang terjadi sebelum tanggal publikasi informasi keuangan di Internet atau website perusahaan mengindikasikan adanya kebocoran informasi. Kebocoran informasi diduga disebabkan perbedaan waktu antara publikasi laporan keuangan melalui internet dan penyampaian laporan keuangan ke Bursa Efek Indonesia. Munculnya abnormal return sejak tanggal pengungkapan IFR menunjukan pasar modal di Indonesia adalah efisiensi bentuk setengah kuat. Hal ini ditunjukan dengan kecepatan pasar bereaksi dimulai sejak hari terjadinya pengungkapan IFR.

Penelitan ini berhasil membuktikan adanya pengaruh tingkat informasi pengungkapan IFR terhadap reaksi investor. Namun, tidak berhasil membuktikan bahwa ruang lingkup pengungkapan IFR berpengaruh terhadap abnormal return saham perusahaan. Kecilnya prosentase terhubungnya website perusahaan ke website BEI dapat menjadi penyebab variabel ruang lingkup pengungkapan IFR tidak berpengaruh terhadap abnormal return saham perusahaan.

Selanjutnya, hasil pengujian kecepatan reaksi investor antara perusahaan yang tingkat pengungkapan IFR tinggi dan perusahaan yang tingkat pengungkapan IFR rendah menunjukan tidak ada perbedaan yang signifikan. 
Reaksi

Investor...

Penelitian dilakukan hanya membentuk satu kelompok sampel perusahaan yang mengungkapkan laporan keuangan di internet tanpa mempertimbangkan sama tidaknya tanggal pengungkapan tersebut dengan penyampain laporan keuangan ke BEI. Perbedaan tanggal antara pengungkapan laporan keuangan di internet dan penyampaian laporan keuangan ke BEI akan meyebabkan informasi yang disampaikan menjadi tidak relevan, sehingga pengujian terhadap reaksi investor menjadi kurang tepat. Oleh karena itu, Penelitian selanjutnya disarankan untuk mempertimbangkan pembentukan dua kelompok sampel, yaitu kelompok sampel perusahaan yang tanggal pengungkapan laporan keuangan di internet sama dengan tanggal penyampaian laporan keuangan ke BEI dan kelompok sampel perusahaan yang tanggal pengungkapan laporan keuangan di internet berbeda dengan tanggal penyampaian laporan keuangan ke BEI. Harapannya pembentukan dua kelompok sampel ini dapat mengukur reaksi investor atas adanya pengungkapan IFR dengan tepat. Penelitian selajutnya juga disarankan untuk menggali lebih lanjut penyebab reaksi investor yang tidak merata di jendela peristiwa.

\section{DAFTAR PUSTAKA}

Abdelsalam, O. \& A. El-Masry. 2008. "The Impact Of Board Independence and Ownership Structure On The Timeliness Of Corporate Internet Reporting By Egyptian listed companies". Managerial Finance, 34(12), 907-918

Aharony, J. \& I. Swary. 1980. "Quartely Devidend and Earnings Announcment and Stocholder's Returns: An Empirical Analysis". Journal Of Finance. 35 (March): 1-12

Akaike, H. 1969. "Fitting Autoregressions for Prediction", Annuals of the Institute of Statistical Mathematics 21:243-247.

Akhiruddin, H. 2013. "Pengaruh Pelaporan Keuangan di Internet Terhadap Reaksi Pasar". Jurnal Ilmiah Mahasiswa.

Almilia, L. S. 2009. "Analisa Komparasi Indeks Internet Financial Reporting Pada Website Perusahaan Go Publik Di Indonesia”. Seminar Nasional Aplikasi Teknologi Informasi 2009 (SNATI 2009)..

Ashbaugh, H., K. Johnstone, \& T. Warfield. 1999. "Corporate Reporting on the Internet”. Accounting Horizons 13(3): 241-257.

Beaver, W. H. 1968. "The Information Content of Annual Earnings Announcements". Journal of Accounting Research 6(3): 67-92.

Craven, B.M. \& Marston, C.L. 1999. "Financial Reporting on the Internet by Leading UK Companies". The Europen Accounting Review, Vol. 8, pp. 321-333.

Easley, D., Hvidkjaer, S, \& M. O'Hara. 2002. "Is Information Risk a Determinant of Asset Returns", Journal of Finance LVII, NO. 5.

Ettredge, M., Richardson, V.J, \& S. Scholz. 2001. "The Presentation of Financial Information at Corporate Web Sites", International Journal of Accounting Information Systems, 2: 149-168.

Fama, Eugene F. 1970. "Efficient market: A Review Of Theory and Empirical Work", Journal of Finance, 25 (2): 383-417.

IDX-Fact Book 2012. Available online at: www.idx.co.id/factbook2012. Diakses tanggal 1 Februari 2013.

Hartono, J. 2010. Teori Portofolio dan Analisis Investasi. BPFE. Yogyakarta.

Khan, T. 2006. "Financial Reporting Disclosure On The Internet: An International Perspective". Faculty of Business and Law School of Accounting, Victoria University, Australia. 
Lai, Syou-Ching., Lin, C., Lee, Hung-Chih., \& Wu, F.H. 2010. "An Empirical Study of the Impact of Internet Financial Reporting on Stock Prices". The International Journal of Digital Accounting Research Vol. 10, 2010, pp. 1-26

Momany, M.T. \& S. A. Al-Shorman. 2006. "Web-Based Voluntary Financial Reporting of Jordanian Companies". International Review of Business Research Papers, 2(2), 127-139

Oyelere, P., Laswad, F. \& Fisher, R. 2003. "Determinants of internet financial reporting by New Zealand companies". Journal of International Financial Management and Accounting, 14(1), 26-61.

Sekaran, U. 2006., Metodologi Penelitian untuk Bisnis. Edisi 4. Salemba Empat, Jakarta.

Venter, J.P.M. 2002. "A Survey Of Current Online Reporting Practices In South Africa". Meditary Accountancy Research, 23. pp. 191-225

Xiao, J. Z., H. Yang \& C. W. Chow. 2004. "The Determinants and Characteristics of Voluntary Internet Based Disclosures by Listed Chinese Companies". Journal of Accounting and Public Policy 23. pp. 191-225. 
